\title{
EXPERIMENTAL NEUROSCIENCES
}

\section{Lazaroid Attenuates Edema by Stabilizing ATPase in the Traumatized Rat Brain}

\author{
Ramazan Durmaz, Güngör Kanbak, Fahrettin Akyüz, Serap Isiksoy, \\ Ferruh Yücel, Mine Inal, Esref Tel
}

\begin{abstract}
Objective: The aim of the present study was to determine the potential therapeutic value of the lazaroid U-83836E on blood brain barrier (BBB) breakdown and edema with respect to the changes in the synaptosomal $\mathrm{Na}^{+} / \mathrm{K}^{+}$and $\mathrm{Mg}^{2+} / \mathrm{Ca}^{2+}$ - adenosinetriphosphatase (ATPase) activities, tissue malondialdehyde levels and the neuronal viability in the rat brain subjected to cerebral trauma. Methods: Traumatic brain injury (TBI) was introduced by applying a $75 \mathrm{gm}$. cm force to the right parietal cortex using the weight-drop method. The first set of animals was used for determining time course changes of the synaptosomal $\mathrm{Na}^{+} / \mathrm{K}^{+}$and $\mathrm{Mg}^{2+} / \mathrm{Ca}^{2+}$-ATPase and the malondialdehyde levels and were sacrificed 2, 6 and $24 \mathrm{~h}$ after lesion production. A group of the animals was treated with U-83836E proir to TBI and sacrificed $24 \mathrm{~h}$ after cerebral injury. A second set of animals was used for evaluating the alterations in BBB disruption and tissue water content and were sacrificed 2, 6 and $24 \mathrm{~h}$ after lesion production. Two groups of animals were treated with U-83836E and sacrificed after 2 and 24h following TBI. U-83836E was given intraperitoneally thirty minutes before trauma at a dose of $10 \mathrm{mg} / \mathrm{kg}$. Neuronal necrosis was also evaluated in the groups of U-83836E and physiological saline-treated animals. Results: Extravasation of Evans blue into the traumatized hemisphere was maximum at $2 \mathrm{~h}(\mathrm{p}<0.001)$ and returned close to the control levels at $24 \mathrm{~h}$ after TBI $(\mathrm{p}>0.05)$. Edema had developed progressively over time and reached the maximum degree of $2.1 \%(\mathrm{p}<0.001)$ at $24 \mathrm{~h}$. U-83836E showed no effect on the BBB breakdown and the tissue water content at $2 \mathrm{~h}$ and still had no effect on the BBB breakdown after $24 \mathrm{~h}$ following the trauma $(\mathrm{p}>0.05)$, although it reduced edema after $24 \mathrm{~h}(\mathrm{p}<0.01)$. $\mathrm{The}$ losses of $\mathrm{Na}^{+} / \mathrm{K}^{+}$and $\mathrm{Mg}^{2+} / \mathrm{Ca}^{2+}-$ ATPase activities were found as $39.5 \%(\mathrm{p}<0.001)$ and $29.4 \%(\mathrm{p}<0.01)$ of the control value, respectively, and remained at the decreased levels throughout the experiment. Malondialdehyde level continued to increase over time reaching up to $209 \%$ (p<0.001) of the control value $24 \mathrm{~h}$ after TBI. Both ATPase activities were improved to near control values ( $>>0.05)$ by the effect of U-83836E. U-83836E inhibited the increase of lipid peroxidation $(\mathrm{p}<0.001)$ and also salvaged neuronal necrosis $(\mathrm{p}<0.05)$. Conclusion: U-83836E given prophylactically after cerebral trauma appears to reduce edema, possibly by inhibiting increases in lipid peroxidation and by stabilizing ATPase. Further studies are recommended to verify the similar effects of the brain penetrating lazaroids when they are given after trauma.
\end{abstract}

RÉSUMÉ: Le lazaroïd (U-83836E) atténue l'oedème en stabilisant l'activité $\mathrm{Na}^{+} / \mathrm{K}^{+}$et $\mathrm{Mg}^{2+} / \mathrm{Ca}^{2+}$-ATPase dans le cerveau de rat traumatisé. Objectif: Le but de cette étude était de déterminer la valeur thérapeutique potentielle du lazaroïd U-83836E sur l'effondrement de la barrière hémato-encéphalique et l'œdème par l'évaluation des changements dans l'activité $\mathrm{Na}^{+} / \mathrm{K}^{+}$et $\mathrm{Mg}^{2+} / \mathrm{Ca}^{2+}$-ATPase synaptosomale, les niveaux de malondialdéhyde tissulaire et la viabilité neuronale dans le cerveau de rats soumis à un traumatisme cérébral. Méthodes: La lésion traumatique était induite par la méthode de chute d'un poids appliquant une force de $75 \mathrm{~g} \mathrm{~cm}$ au niveau du cortex pariétal droit. Le premier groupe d'animaux a servi à déterminer les changements dans le temps au niveau des taux synaptosomaux de $\mathrm{Na}^{+} / \mathrm{K}^{+}$ et $\mathrm{Mg}^{2+} \mathrm{Ca}^{2+}$-ATPase et de malondialdéhyde tissulaire et ils ont été sacrifiés 2, 6 et 24 heures après avoir subi le traumatisme. Un premier groupe d'animaux a été traité par le U-83836E et sacrifié 24 heures après le traumatisme. Un second groupe d'animaux a servi à évaluer les altérations de la barrière hémato-encéphalique et le contenu tissulaire aqueux. Ils ont été sacrifiés 2, 6 et 24 heures après le traumatisme. Deux groupes d'animaux ont été traités par le U-83836E et sacrifiés soit 2 heures ou 24 heures après la lésion. Le U-83836E a été administré par voie intrapéritonéale trente minutes avant le traumatisme à la dose de $10 \mathrm{mg} / \mathrm{k}$. La nécrose neuronale a été évaluée chez le groupe d'animaux ayant reçu le U-83836E et chez le groupe ayant reçu du soluté physiologique. Résultats: L'extravasation du Bleu Evans dans l'hémisphère traumatisé était à son maximum 2 heures après le traumatisme $(p<0,001)$ et rejoignait celle des témoins après 24 heures $(p<0,05)$. L'œedème apparaissait progressivement et était à son maximum de $2,1 \%(\mathrm{p}<0,001)$ après 24 heures. Le U-83836E n'avait aucun effet sur l'altération de la barrière hématoencéphalique et le contenu tissulaire aqueux après 2 heures et n'avait toujours pas d'effet sur l'altération de la barrière hémato-encéphalique après 24 heures ( $\mathrm{p}<0,05$ ),


et 29,4\% (p<0,01) de la valeur témoin respectivement et sont demeurées à des niveaux abaissés pendant toute la durée d'observation. Le niveau de malondialdéhyde a continué à augmenter, atteignant 209\% (p<0,001) de la valeur témoin 24 heures après le traumatisme. Les deux activités ATPase étaient améliorées par l'effet du U-83836E, à des niveaux voisins de ceux des témoins ( $\mathrm{p}<0,05)$. Le U-83836E a inhibé l'augmentation de la peroxydation lipidique ( $\mathrm{p}<0,001)$ et protégé de la nécroses neuronale $(\mathrm{p}<0,05)$. Conclusion: Le U-83836E administré de façon prophylactique après un traumatisme cérébral semble diminuer l'œdème. Il est possible que ce soit dû à l'inhibition de l'augmentation de la peroxydation lipidique et à la stabilisation des ATPases. Des études plus poussées devraient être entreprises afin de vérifier les effets des lazaroïds qui pénètrent dans le cerveau, quand ils sont administrés après un traumatisme.

Can. J. Neurol. Sci. 2003; 30: 143-149

Brain edema associated with the traumatic brain injury (TBI) is a clinical phenomenon that exacerbates delayed cell death and may threaten life for some patients. Edema formation following a primary cerebral insult is seen as a sequela of secondary
From the Departments of Neurosurgery (RD, ET), Biochemistry (GK, FA, MI), Pathology (SI) and Anatomy (FY), Medical Faculty of Osmangazi University, TR26480, Eskisehir, Turkey.

ReCeived May 29, 2002. ACCEPTEd In FinAl FORM OCtOBER 22, 2002. Reprint requests to: Ramazan Durmaz, Neurosurgical Department, Medical Faculty of Osmangazi University, 26480, Eskisehir, Turkey 
molecular and physiological events, including N-methyl-Dreceptor activation, release of oxygen free radicals and fatty acids, lipid peroxidation, acidosis, disturbance of ionic gradients and the breakdown of the blood-brain barrier (BBB). ${ }^{1-4} \mathrm{Na}^{+} / \mathrm{K}^{+}$ and $\mathrm{Mg}^{2+} / \mathrm{Ca}^{2+}$-adenosinetriphosphatase (ATPase) are membrane-bound enzymes, which regulate intracellular $\mathrm{Na}^{+}$, $\mathrm{Mg}^{2+}$ and $\mathrm{Ca}^{2+}$ concentrations. In presynaptic vesicles of the nerve terminals there is a high activity of $\mathrm{Ca}^{2+}$-ATPase and the phospholipid content of the synaptosomal membrane is essential for the activity of $\mathrm{Na}^{+} / \mathrm{K}^{+}$-ATPase. ${ }^{5,6}$

Klatzo $^{7}$ has classified brain edema into two main forms; vasogenic and cytotoxic. Vasogenic edema is defined as the extracellular space enlargement induced by BBB breakdown. Cytotoxic edema is characterized by intracellular water accumulation resulting from the cessation of ionic pumps, in turn caused by an interruption of energy supply. However, severe cellular injury is required for persistent cytotoxic swelling of the cells. ${ }^{8}$ The 21-aminosteroids (lazaroids) are potent lipid peroxidation inhibitors that have been demonstrated to protect neuronal tissue and the $\mathrm{BBB}$ from the peroxidative damage in a number of experimental models. ${ }^{9-14}$ They are effective in lowering post-ischemic and post-traumatic tissue-water content, ${ }^{15,16}$ possibly by attenuating $\mathrm{BBB}$ breakdown, since they are not expected to cross the BBB. ${ }^{14} \mathrm{U}-83836 \mathrm{E}[(-)$ 2-((2,6-di-1pyrrolidinyl-4-pyrimidinyl)-1-piperazinyl)methyl)-3,4dihydro2,5,7,8-tetramethyl-2H-1-benzopyran-6-ol dihydrochloride] is a second generation lazaroid that combines the amino functionalities of the 21-aminosteroids with the antioxidant ring of $\alpha$-tocopherol and has access into the brain parenchyma. ${ }^{12}$ We aimed to assess the potential therapeutic value of $\mathrm{U}-83836 \mathrm{E}$ on $\mathrm{BBB}$ disruption and the edema following traumatic brain injury. In particular, we examined changes in synaptosomal $\mathrm{Na}^{+} / \mathrm{K}^{+}$and $\mathrm{Mg}^{2+} / \mathrm{Ca}^{2+}-$ ATPase activities, lipid peroxidation and neuronal viability.

\section{MATERIALS AND METHODS}

\section{Experimental protocol}

A total of 104 adult male Spraque-Dawley rats weighing 250$320 \mathrm{~g}$ were studied. The animals were anesthetized by intraperitoneal injection of a mixture of ketamine hydrochloride
$(60 \mathrm{mg} / \mathrm{kg})$ and xylasine $(12 \mathrm{mg} / \mathrm{kg})$. Atropine sulfate $(10 \mathrm{mg} / \mathrm{kg})$ was also given in order to prevent pulmonary secretions. The trachea was intubated with a 14-gauge angiocatheter and the lungs were mechanically ventilated with a mixture of oxygen and room air using a small rodent ventilator (Ugo Basile Biological Research Apparatus). Throughout the experiment the tidal volume was $1.8 \mathrm{ml}$ and the ventilation setting was adjusted to maintain arterial $\mathrm{CO}_{2}$ and $\mathrm{O}_{2}$ pressure within the desired limits. Arterial blood samples were taken from the left ventricle by a tuberculin syringe. The right femoral artery was catheterized for continuous blood pressure recording. The experiment was performed under normotensive conditions and the rectal temperature was maintained by an automated heatlamp at approximately $37^{\circ} \mathrm{C}$. Blood gases are shown in the Table.

We designed a new device to semi-automate the experimental trauma method of Feeney. ${ }^{17}$ After a craniotomy had been made, brain injury was introduced using an electrical circuit switch which caused a $10 \mathrm{~g}$ brass rod to drop from a distance of $7.5 \mathrm{~cm}$, through a plexiglass guide tube, onto the exposed dura over the right parietal cortex.

The first set of animals was used to determine the time-course of tissue changes of the $\mathrm{Na}^{+} / \mathrm{K}^{+}$and $\mathrm{Mg}^{2+} / \mathrm{Ca}^{2+}$-ATPase activities and malondialdehyde (MDA) in the traumatized hemisphere. A group of the animals $(n=6)$ undergoing craniotomy operation alone was used as a control and sacrificed after $24 \mathrm{~h}$. Three groups of animals (each $n=9$ ) were killed at various time points; 2,6 and $24 \mathrm{~h}$ after cerebral injury. U-83836E was dissolved in 0.9 $\%$ saline solution with a final concentration of $12.5 \mathrm{mg} / \mathrm{ml}$. Vehicle was saline alone. Thirty minutes prior to trauma, a group of animals was administered a single intraperitoneal dose of 10 $\mathrm{mg} / \mathrm{kg}$ of $\mathrm{U}-83836 \mathrm{E}(\mathrm{n}=9)$ or vehicle $(\mathrm{n}=7)$ and sacrificed $24 \mathrm{~h}$ after cerebral injury.

A second set of animals was used for determining the timecourse of BBB breakdown and tissue water-content changes in the traumatized hemisphere. Sham-operated animals $(n=6)$ were sacrificed after $24 \mathrm{~h}$ and served as a control. Three groups of animals (each $\mathrm{n}=7$ ) were sacrificed at various time points; 2, 6 and $24 \mathrm{~h}$ after cerebral injury. Two groups of animals (each $\mathrm{n}=7$ ) were treated with $\mathrm{U}-83836 \mathrm{E}$ at a dose of $10 \mathrm{mg} / \mathrm{kg}$ or vehicle $(n=6) 30$ minutes prior to trauma and sacrificed 2 and $24 \mathrm{~h}$ after

Table: Data for blood pH and Gas levels, A) in the first, and B) in the second set of animals. Values are given as mean \pm SEM.

\begin{tabular}{|c|c|c|c|c|c|c|c|}
\hline $\mathbf{A}$ & & & & & & & \\
\hline Groups & Sham & $2 \mathrm{~h}$ & $6 \mathrm{~h}$ & $24 \mathrm{~h}$ & U83836E-treated & Saline-treated & \\
\hline $\mathrm{pH}$ & $7.47 \pm 0.02$ & $7.41 \pm 0.02$ & $7.44 \pm 0.03$ & $7.46 \pm 0.02$ & $7.45 \pm 0.02$ & $7.49 \pm 0.06$ & \\
\hline $\mathrm{P}_{\mathrm{a}} \mathrm{CO}_{2} \mathrm{~mm} \mathrm{Hg}$ & $35.3 \pm 1.4$ & $33.5 \pm 1.2$ & $37.4 \pm 1.2$ & $34.7 \pm 1.2$ & $35.9 \pm 2.0$ & $35.5 \pm 1.1$ & \\
\hline $\begin{array}{l}\mathrm{P}_{\mathrm{a}} \mathrm{O}_{2} \mathrm{~mm} \mathrm{Hg} \\
\mathbf{B}\end{array}$ & $113 \pm 9.7$ & $119 \pm 12.0$ & $123 \pm 11.0$ & $157 \pm 18.5$ & $140 \pm 13.2$ & $142 \pm 13.5$ & \\
\hline Groups & Sham & $2 \mathrm{~h}$ & $6 \mathrm{~h}$ & $24 \mathrm{~h}$ & $\begin{array}{l}\text { U83836E- } \\
\text { treated/2 h }\end{array}$ & $\begin{array}{l}\text { U83836E- } \\
\text { treated/24 h }\end{array}$ & $\begin{array}{l}\text { Saline- } \\
\text { treated } / 24 \text { h }\end{array}$ \\
\hline $\mathrm{pH}$ & $7.34 \pm 0.10$ & $7.48 \pm 0.02$ & $7.54 \pm 0.03$ & $7.40 \pm 0.14$ & $7.46 \pm 0.15$ & $7.39 \pm 0.02$ & $7.58 \pm 0.02$ \\
\hline $\mathrm{P}_{\mathrm{a}} \mathrm{CO}_{2} \mathrm{~mm} \mathrm{Hg}$ & $33.0 \pm 1.1$ & $36.5 \pm 1.2$ & $38.6 \pm 2.1$ & $35.2 \pm 1.2$ & $36.1 \pm 1.2$ & $36.9 \pm 1.0$ & $37.5 \pm 1.3$ \\
\hline $\mathrm{P}_{\mathrm{a}} \mathrm{O}_{2} \mathrm{~mm} \mathrm{Hg}$ & $164 \pm 14.5$ & $124 \pm 15.1$ & $118 \pm 11.0$ & $139 \pm 17.3$ & $152 \pm 20.1$ & $125 \pm 12.2$ & $112 \pm 10.4$ \\
\hline
\end{tabular}


cerebral injury. After animals had been reanesthetized, Evans blue dye $(2 \%, 5 \mathrm{ml} / \mathrm{kg})$ was given intravenously an hour before sacrifice. Approval for the study was granted by The Committee on Animal Experiments of the Medical Faculty of Osmangazi University and all experimental procedures were performed in accordance with the National Institute of Health's Principles of Laboratory Animal Care.

Rats of set 1 and 2 were perfused with $200 \mathrm{ml}$ physiological saline through the left ventricle using an infusion pump. Animals were killed by an overdose of the mixture of anesthetic drugs described above or an additional dose in the second set of animals. After decapitation, the brains were immediately removed, frozen in liquid nitrogen and stored at $-80^{\circ} \mathrm{C}$.

Histological examination was performed on a third set of animals. One group $(n=4)$ was treated with physiological saline, the other $(n=4)$ with $\mathrm{U}-83836 \mathrm{E} 30$ minutes prior to trauma. Before sacrifice at $24 \mathrm{~h}$, the brains were fixed with $200 \mathrm{ml}$ buffered formalin (2\%), after $50 \mathrm{ml}$ physiological saline perfusion through the left ventricle. After the removal of the brains, coronal sections were made and tissue blocks $2 \mathrm{~mm}$ in thickness were excised and fixed in $10 \%$ buffered formalin. The sections were stained with hematoxylin and eosin, and acid fuchsine.

\section{Morphometry}

In the traumatized hemisphere, a coronal section was made through the center of the lesion. The volume fraction of the dead neurons of the cortical tissue was determined by "point count" analysis at the light microscopic level, as previously applied. ${ }^{18,19}$ Counts were made from the surface to the base of the neocortex, using three adjacent frames in which a lattice (quadratic test frame) was superimposed randomly on a microscopical field sampled within the section, with the other frames evenly spaced. To calculate the volume fraction of acid-fuchsine positive neurons which are presumed to be moribund cells, ${ }^{20,21}$ the number of points of acidophilic neurons throughout the entire cortical layer was divided by the number of points on the lattice.

\section{Evaluation of edema and BBB breakdown}

The water content in the injured hemisphere was calculated using wet weight to dry weight ratios as described previously. ${ }^{22}$ Subsequently, Evans blue content of the dried tissue of the traumatized hemisphere was measured using a spectrophotometer (Schimadzu UV-1201) at the wavelength of $660 \mathrm{~nm} .{ }^{23}$ Results were presented as $\mu \mathrm{g} / \mathrm{g}$ dried weight.

\section{Preparation of brain synaptosomes and assay of membrane- bound ATPase activities}

After thawing the brain at $4^{\circ} \mathrm{C}$, two blocks of samples of $3 \mathrm{~mm}$ thickness were taken by coronal section from the center of the area of trauma and used for the determination of the $\mathrm{Na}^{+} / \mathrm{K}^{+}$and $\mathrm{Mg}^{2+} / \mathrm{Ca}^{2+}$-ATPase activities and MDA levels. Preparation of synaptosomes was according to the method of Braughler and Hall. ${ }^{24}$ In these preparations, the $\mathrm{Na}^{+} / \mathrm{K}^{+}$and $\mathrm{Mg}^{2+} / \mathrm{Ca}^{2+}$-ATPase activities were assayed as previously described ${ }^{25}$ and the results were expressed as $\mathrm{U} / \mathrm{mg}$ protein.

\section{Lipid peroxide assay}

Tissue peroxide was measured by the colorimetric reaction of thiobarbituric acid-reactive substances in the presence of MDA at $532 \mathrm{~nm}$, according to the method of Ohkawa et al. ${ }^{26}$ The results were expressed as $\mathrm{nM} / \mathrm{mg}$ protein. Proteins were determined by using a commercial protein detection kit based on the method of Lowry et al. ${ }^{27}$

\section{Statistical analysis}

The data were normally distributed and the data analysis was performed using statistical analysis software. ${ }^{28}$ The significance of the differences between the groups was ascertained by oneway analysis of variance, followed by the Bonferroni test for multiple comparisons. In order to compare the neuronal loss between the vehicle- and the U-83836E-treated groups, a onetailed t test was used. Statistical significance was defined by a $\mathrm{p}$ value $<0.05$.

\section{RESUlts}

When compared to the control, extravasation of Evans blue into the traumatized hemisphere was maximum at $2 \mathrm{~h}(\mathrm{p}<0.001)$, started to decline at $6 \mathrm{~h}(\mathrm{p}<0.01)$ and returned close to control levels at $24 \mathrm{~h}$ after TBI $(\mathrm{p}>0.05$, Figure 1). No significant difference in the dye concentration was observed between 6 and $24 \mathrm{~h}(\mathrm{p}>0.05)$, but there was a difference, which was observed between 2 and $6 \mathrm{~h}(\mathrm{p}<0.01)$. The water content of the traumatized hemisphere increased in a time-dependent manner and reached maximal levels at 24h (Figure 2A). Compared to the control, TBI caused an increase in the water content of the injured hemisphere; $0.5 \%(\mathrm{p}>0.05)$ at $2,1.3 \%$ at $6 \mathrm{~h}(\mathrm{p}<0.001)$, and $2.1 \%$ $(\mathrm{p}<0.001)$ at $24 \mathrm{~h}$, respectively. The increases in the edema at 2 to 6 and 6 to 24 hours were also significant $(\mathrm{p}<0.01)$. Pre-treatment of animals with the lazaroid U-83836E did not influence BBB breakdown at 2 and $24 \mathrm{~h}$ or edema at $2 \mathrm{~h}$ after TBI. On the other hand, the agent attenuated edema at $24 \mathrm{~h}$ compared to the results of saline-treated animals $(\mathrm{p}<0.01$, Figure $2 \mathrm{~B})$.

Loss in synaptosomal $\mathrm{Na}^{+} / \mathrm{K}^{+}$-ATPase activity in the rat brain homogenate of the traumatized hemisphere occurred in the early period following the trauma and remained close to this level at 6 and $24 \mathrm{~h}$ after TBI; $39.5 \%(\mathrm{p}<0.001)$ at $2 \mathrm{~h}, 37.9 \%(\mathrm{p}<0.01)$ at $6 \mathrm{~h}$, and $37.8 \%$ of the control $(\mathrm{p}<0.01)$ at $24 \mathrm{~h}$ post-trauma (Figure $3 \mathrm{~A})$. Similarly, a decrease in the $\mathrm{Mg}^{2+} / \mathrm{Ca}^{2+}$-ATPase activity was observed during the early hours after TBI, with a temporary elevation at $6 \mathrm{~h}$ and a maximum decrease at $24 \mathrm{~h}$. Losses in the activity of $\mathrm{Mg}^{2+} / \mathrm{Ca}^{2+}$-ATPase were $29.4 \%(\mathrm{p}<0.01)$ of control at $2 \mathrm{~h}, 16.7 \%(\mathrm{p}>0.05)$ at $6 \mathrm{~h}$, and $42.5 \%(\mathrm{p}<0.001)$ at $24 \mathrm{~h}$ posttrauma (Figure 3A). The decrease in both the $\mathrm{Na}^{+} / \mathrm{K}^{+}$and $\mathrm{Mg}^{2+} / \mathrm{Ca}^{2+}$-ATPase activities was restored to control values by U-83836E given prophylactically (Figure 3B).

Malodialdehyde content of the injured tissue increased, reaching maximal levels at $24 \mathrm{~h}$ post-trauma (Figure $4 \mathrm{~A}$ ). Levels were $122 \%(p>0.05)$ of the control at $2 \mathrm{~h}, 136 \%(\mathrm{p}<0.01)$ at $6 \mathrm{~h}$, and $209 \%(\mathrm{p}<0.001)$ at $24 \mathrm{~h}$ post-injury. The U-83836E-treated animals had a significantly lower MDA content in the injured tissue than those of the saline-treated animals $(\mathrm{p}<0.001$, Figure 4B).

Twenty-four hours after trauma, the TBI region contained hemorrhage and some cavitations. Microscopically, there was edema, congestion, hemorrhage and infarction in the areas of the impact side, including the thalamus and subthalamus. The infarcted area was pale and edematous including disintegrated cells (Figure 5A). There were injured neurons in the cortical 

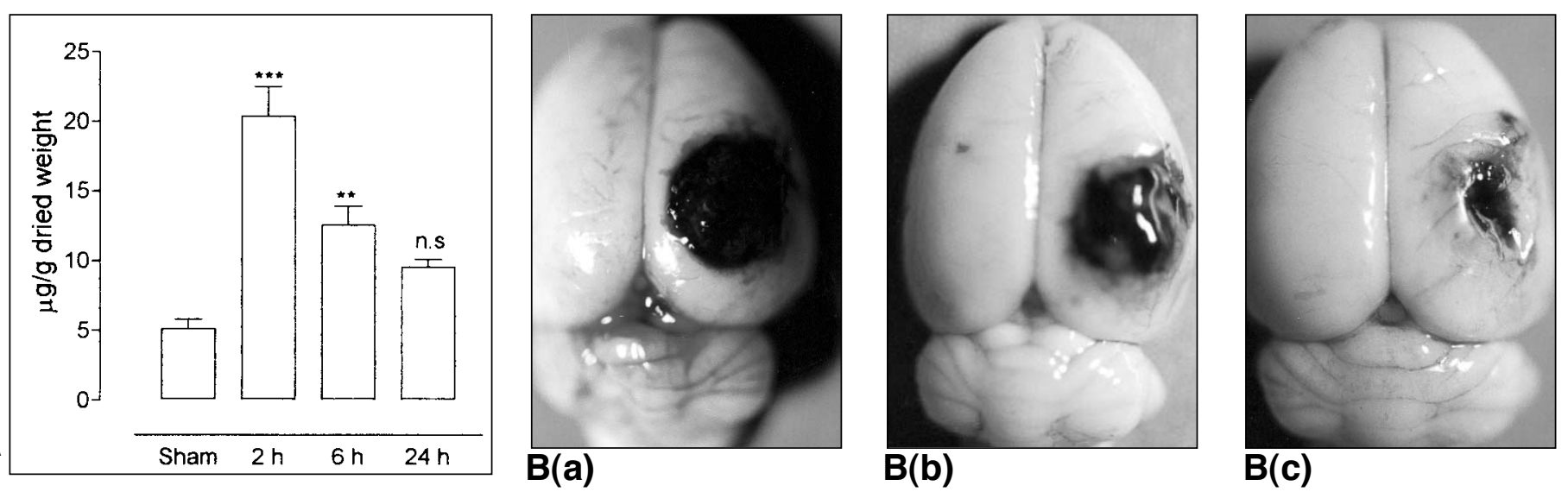

Figure 1: A) The extravasation of Evans blue dye into the traumatized hemisphere. Each bar shows the mean Evans blue content of traumatized hemisphere \pm SEM. Asterix denotes the significant difference from control. n.s: not significant, ** Significant at $p<0.01$ and $* * * p<0.001$. B) Gross appearance of Evans blue extravasation into injured brain a) at $2 h, b) 6 h$ and c) $24 h$ after trauma.

A

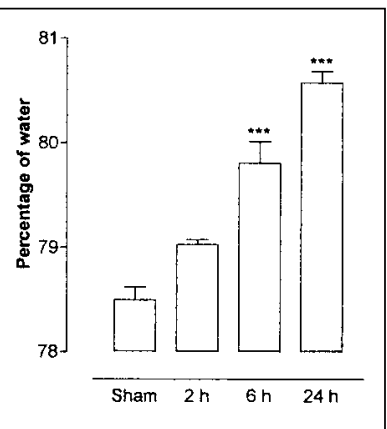

B

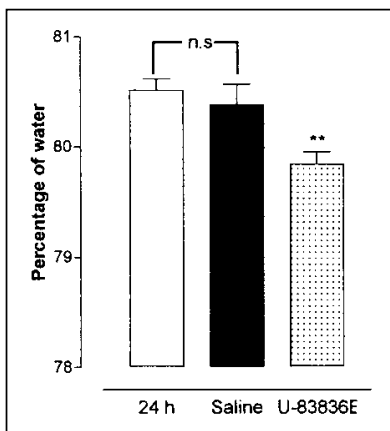

Figure 2: Graph shows A) an increase in the water content of the traumatized hemisphere when compared to control and, B) attenuation of $24 \mathrm{~h}$ post-traumatic edema by the effect of $U-83836 E$ when compared to saline-treated group and also untreated group of animals (which were those sacrificed $24 \mathrm{~h}$ after trauma). Values are given as mean \pm SEM. Asterix denotes the significant difference. n.s: not significant, ${ }^{* *}$ Significant at $p<0.01$ and $* * * p<0.001$.

A

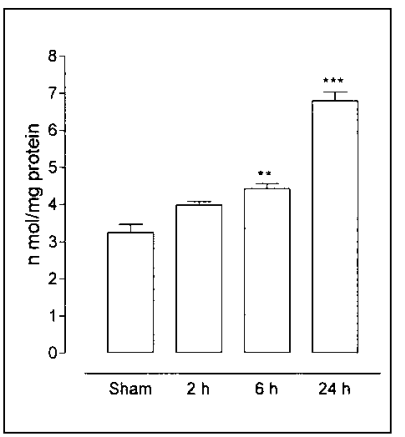

B

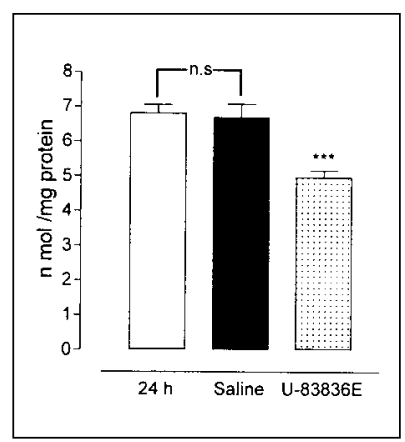

Figure 4: Graph shows A) the tissue changes of MDA levels over time in the injured hemisphere when compared to control and, B) the reduction of tissue MDA content by the effect of $U-83836 E$ when compared to saline-treated group and also untreated group of animals (which were those sacrificed 24 h after trauma). Values are given as mean \pm SEM. Asterix denotes the significant difference. n.s: not significant, $* *$ Significant at $p<0.01$ and $* * * p<0.001$.
A

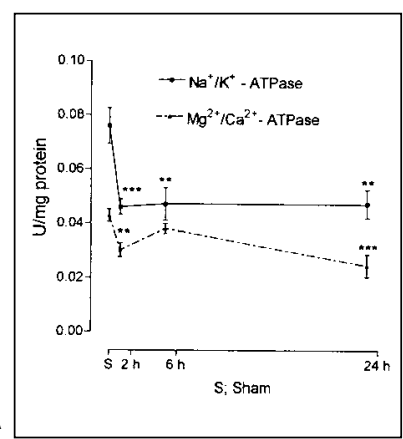

B

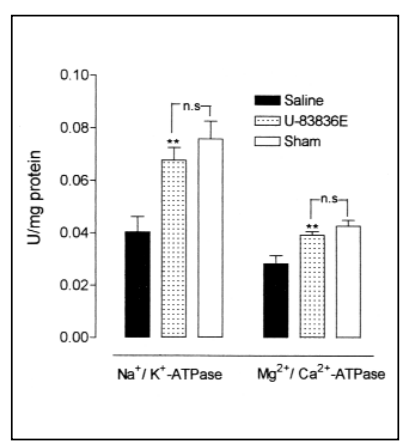

Figure 3: Graph shows A) the changes of synaptosomal $\mathrm{Na}^{+} / \mathrm{K}^{+}$and $\mathrm{Mg}^{2+} / \mathrm{Ca}^{2+}$ ATPase activities over time in the traumatized hemisphere when compared to control and, B) enhancement of the activities of $\mathrm{Na}^{+} / \mathrm{K}^{+}$and $\mathrm{Mg}^{2+} / \mathrm{Ca}^{2+}$ ATPase by $\mathrm{U}-83836 \mathrm{E}$ when compared to the sham-operated group of animals $(p>0.05)$; there was significant difference between the groups of animals treated with $U-83836 E$ and saline $(p<0.01)$. Values are given as mean \pm SEM. Asterix denotes the significant difference. n.s: not significant, $* *$ significant at $p<0.01$ and $* * * p<0.001$. 
A

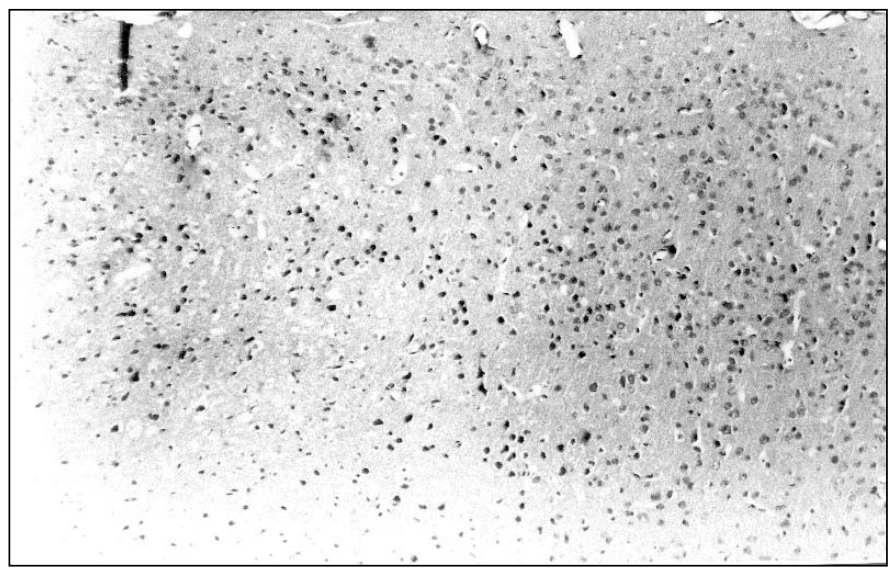

Figure 5: A) The infarcted region is pale and edematous $24 \mathrm{~h}$ after cerebral injury (on the left side). There are vacuolizations within neuroglial cells, in perineural locations and the interstitium, which are compatible with edema. In the cortical areas adjacent to the infarct side there are injured dark neurons (Hematoxylin and eosin X 40). B) Severely damaged neurons stained positively with acid fuchsine can be seen in the cortical areas (acid fuchsine X 20).

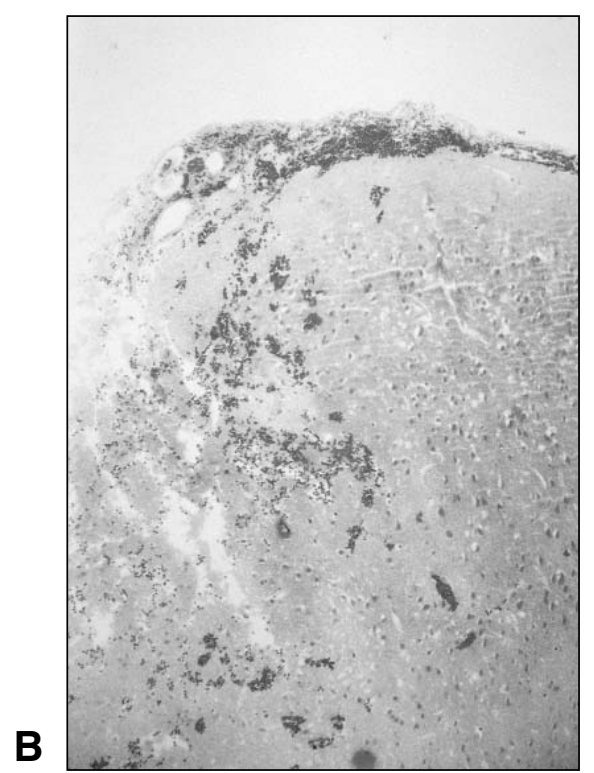

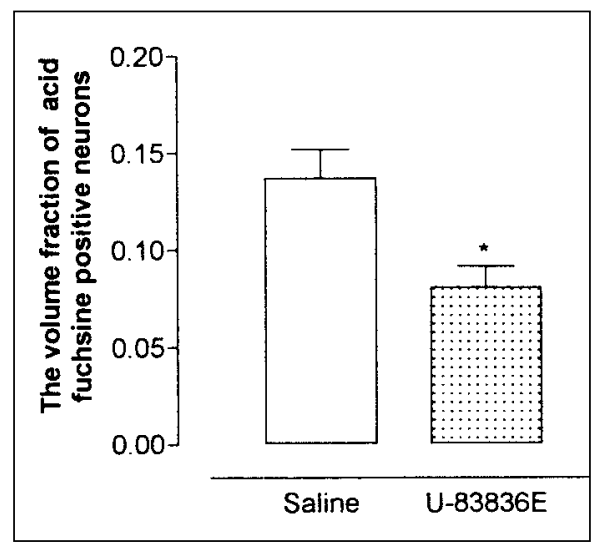

Figure 6: Bar graph of attenuation of 24 hosttraumatic cortical neuronal necrosis by $U$ $83836 E$ (one-tailed " $t$ " test). Values are given as mean \pm SEM. Asterix denotes the significant difference from control. * Significant at $p<0.05$.

regions of the brain adjacent to the impact and also in the contralateral hemisphere. The injured neurons had shrunken cell bodies with condensed cytoplasm and pyknotic nuclei, which were stained with acid fuchsine (Figure 5B). The volume fraction of dying neurons in the cortical layer was found to be significantly lower $(\mathrm{p}<0.05)$ in the U-83836E-treated rats than in those of saline-treated animals (Figure 6).

\section{Discussion}

In the present study, BBB breakdown in the injured hemisphere after TBI was maximum at $2 \mathrm{~h}$ following the trauma, showed a decline at $6 \mathrm{~h}$ and returned close to the control at $24 \mathrm{~h}$.
This suggests that maximal BBB breakdown occurs during the early hours following trauma and returns to normal values at $24 \mathrm{~h}$, as previously shown. ${ }^{29,30}$ Blood-brain barrier breakdown has been found to be greater after focal injury than after diffuse injury, ${ }^{29}$ although BBB disruption is transient in both models. ${ }^{31,32}$ Edema in the injured hemisphere showed a progressive development, although no significant increase occurred until $6 \mathrm{~h}$ after the trauma. Our finding supports the study of Barzo et al;33 widespread post-trauma edema formation occurred later, due predominantly to cellular swelling.

In the present study, inhibition of $\mathrm{Na}^{+} / \mathrm{K}^{+}$-ATPase activity was observed in the early phases following the trauma and remained at a decreased level throughout the first $24 \mathrm{~h}$. A similar result was obtained in the studies of Ildan et $\mathrm{al}^{34}$ and Jamme et al, ${ }^{35}$ in which $\mathrm{Na}^{+} / \mathrm{K}^{+}$-ATPase activity diminished within a short period following the focal cerebral ischemia model in rats and remained below the control level over 120 minutes. On the other hand, the inhibition in the $\mathrm{Mg}^{2+} / \mathrm{Ca}^{2+}$-ATPase activity occurred soon after the trauma and became particularly marked at $24 \mathrm{~h}$. This result is in accordance with the study of Parson et $\mathrm{al}^{36}$ in which the inhibition of microsomal $\mathrm{Mg}^{2+} / \mathrm{Ca}^{2+}$-ATPase activity in rat brain subjected to global ischemia had increased to the maximum level after 60 minutes. In our study, the losses in the activities of $\mathrm{Na}^{+} / \mathrm{K}^{+}$and $\mathrm{Mg}^{2+} / \mathrm{Ca}^{2+}$-ATPase were not time-dependent, while the increase in MDA and the tissue water content was timedependent, suggesting that the mechanisms for maintenance of ionic homeostasis of the cells was not attributable to membrane fluidity alone. This finding supports observations that stressinduced oxidation and ischemia in the rat brain causes inhibition of $\mathrm{Na}^{+} / \mathrm{K}^{+}$-ATPase and a rise in intracellular $\mathrm{Na}^{+}$and $\mathrm{Ca}^{2+}$ concentrations, without changes in lipid peroxidation. ${ }^{37,38}$ Experimental evidence suggests that the plasma membrane enzymes are a target site for neuroactive steroid action; methylprednisolone has been demonstrated to enhance $\mathrm{Na}^{+} / \mathrm{K}^{+}$ and $\mathrm{Mg}^{2+}$-activated ATPase in the focal cerebral ischemia and 
spinal cord trauma animal models. ${ }^{24,34}$ The present study provides evidence that $\mathrm{U}-83836 \mathrm{E}$ given prophylactically, enhances $\mathrm{Na}^{+} / \mathrm{K}^{+}$and $\mathrm{Mg}^{2+} / \mathrm{Ca}^{2+}$-ATPase activities, possibly by scavenging iron-catalyzed free radical formation, and inhibiting lipid peroxidation, ${ }^{9}$ the latter of which was shown in our previous study. ${ }^{39}$

21-aminosteroids have been shown to reduce edema in ischemic and traumatic brain injury, ${ }^{15,16,40}$ possibly protecting the BBB from peroxidative damage. ${ }^{10-13}$ However, they appear to act mainly on microvascular endothelium and have been demonstrated to ameliorate BBB breakdown more potently than brain penetrable lazaroids. ${ }^{14,41} \mathrm{~A}$ brain penetrating lazaroid, U$83836 \mathrm{E}$, demonstrated no effect on the BBB breakdown or the early edema development in the present study. However, Schoettle et $\mathrm{al}^{42}$ have concluded that an increase in the tissue water content of a damaged hemisphere in the early phase after trauma most likely represents the combination of hemorrhage, vasodilation, and edema in focal brain injury models. In the present study, tissue water content and MDA levels increased progressively, reaching a maximum level at $24 \mathrm{~h}$, which may suggest a close relationship between edema formation and lipid peroxidation after TBI. It seems that in later hours edema may be mostly of the cytotoxic type, although the BBB breakdown contributes to edema development in the early phase after trauma. When given prophylactically, U-83836E reduced edema at $24 \mathrm{~h}$, possibly inhibiting the increase of lipid peroxidation and enhancing the activities of $\mathrm{Na}^{+} / \mathrm{K}^{+}$and $\mathrm{Mg}^{2+} / \mathrm{Ca}^{2+}$-ATPase that cause intracellular $\mathrm{Ca}^{2+}$ and $\mathrm{Na}^{+}$overload, cellular edema and cell death. ${ }^{43}$

In the present study, the traumatic area had a spongy appearance, involving necrosis and dying neurons. Acidophilic neurons were most prominent in the contused cortex at 6 and $24 \mathrm{~h}$ after TBI, ${ }^{21}$ with concomitant accumulation of calcium in the cells. ${ }^{44}$ Pretreatment with U-83836E salvaged neuronal necrosis. This outcome was consistent with previous observations that the brain penetrating lazaroid $\mathrm{U}-78517 \mathrm{~F}$ (U-83836E is the minus enantiomer of the racemic compound of U-78517F), amelioration of post-ischemic neuron necrosis is more potent than 21-aminosteroid. ${ }^{11,12}$

In conclusion, these results suggest that the brain penetrating lazaroids, when given prophylactically, may be beneficial in the treatment of TBI. Further studies are recommended to determine if similar effects of the second generation of lazaroids are observed when they are given after the trauma.

\section{REFERENCES}

1. Braughler JM, Hall ED. Central nervous system trauma and stroke. I. Biochemical considerations for oxygen radical formation and lipid peroxidation. Free Radic Biol Med 1989; 6: 289-301.

2. Chan PH, Fishman RA, Longar S, Chen S, Yu A. Cellular and molecular effects of polyunsaturated fatty acids in brain ischemia and injury. Prog Brain Res 1985;63:227-235.

3. Faden AI, Demediuk P, Panter SS, Vink R. The role of excitatory amino acids and NMDA receptors in traumatic brain injury. Science 1989;244:798-800.

4. Oury TD, Piantadosi CA, Crapo JD. Cold-induced brain edema in mice. Involvement of extracellular superoxide dismutase and nitric oxide. J Biol Chem 1993;268:15394-15398.

5. Lin SC, Way EL. A high affinity $\mathrm{Ca}^{2+}$-ATPase in enriched nerveending plasma membranes. Brain Res 1982;235: 387-392.

6. Sun AY, Sun GY, Samorajski T. The effect of phospholipase C on the activity of adenosine triphosphatase and acetylcholinesterase in synaptic membranes isolated from the cerebral cortex of squirrel monkey. J Neurochem 1971;18:1711-1768.

7. Klatzo I. Evolution of brain edema concept. Acta Neurochir Suppl (Wien) 1994;60:3-4.

8. Klatzo I. Presidental address. Neuropathological aspects of brain edema. J Neuropathol Exp Neurol 1967;26:1-14.

9. Braughler JM, Pregenzer JF. The 21-aminosteroid inhibitors of lipid peroxidation: reactions with lipid peroxyl and phenoxy radicals. Free Radic Biol Med 1989;7:125-130.

10. Hall ED, Travis MA. Inhibition of arachidonic acid-induced vasogenic brain edema by the non-glucocorticoid 21-aminostroid U74006F. Brain Res 1988;451:350-352.

11. Hall ED, Pazara KE, Braughler JM, Linseman KL, Jacobsen EJ. Nonsteroidal lazaroid U78517F in models of focal and global ischemia. Stroke 1990; 21(11 Suppl):III83-III87.

12. Hall ED, Braughler JM, Yonkers PA, et al. U-78517F: a potent inhibitor of lipid peroxidation with activity in experimental brain injury and ischemia. J Pharmacol Exp Ther 1991;258:688-694.

13. Hall ED, McCall JM, Means ED. Therapeutic potential of the lazaroids (21-aminosteroids) in acute central nervous system trauma, ischemia and subarachnoid hemorrhage. Adv Pharmacol 1994;28:221-268.

14. Hall ED, Andrus PK, Smith SL, et al. Neuroprotective efficacy of microvascularly-localized versus brain-penetrating antioxidants. Acta Neurochir Suppl (Wien) 1996;66:107-113.

15. McIntosh TK, Banbury M, Smith D, Thomas M. The novel 21aminosteroid U-74006F attenuates cerebral oedema and improves survival after brain injury in the rat. Acta Neurochir Suppl (Wien) 1990;51:329-330.

16. Young W, Wojak JC, DeCrescito V. 21-Aminosteroid reduces ion shifts and edema in the rat middle cerebral artery occlusion model of regional ischemia. Stroke 1988;19:1013-1019.

17. Feeney DM, Boyeson MG, Linn RT, Murray HM, Dail WG. Responses to cortical injury: I. Methodology and local effects of contusions in the rat. Brain Res 1981;211:67-77.

18. Mayhew TM, Gundersen HJ. If you assume, you can make an ass out of $\mathrm{u}$ and me': a decade of the disector for stereological counting of particles in 3D space. J Anat 1996;188:1-15.

19. Palkovits M, Magyar P, Szentagothai J. Quantitative histological analysis of the cerebellar cortex in the cat. II. Cell numbers and densities in the granular layer. Brain Res 1971;32:15-30.

20. Auer RN, Siesjö BK. Biological differences between ischemia, hypoglycemia and epilepsy. Ann Neurol 1988;24:699-707.

21. Sutton RL, Lescaudron L, Stein DG. Unilateral cortical contusion injury in the rat: vascular disruption and temporal development of cortical necrosis. J Neurotrauma 1993;10:135-149.

22. Demediuk P, Lemke M, Faden I. Spinal cord edema and changes in tissue content of $\mathrm{Na}, \mathrm{K}$, and $\mathrm{Mg}$ after impact trauma in rats. In: Long D, et al (Eds). Advances in Neurology Vol 52, Raven Press 1990:225-232.

23. Shapira Y, Setton D, Artru AA, Shohami E. Blood-brain barrier permeability, cerebral edema, and neurologic function after closed head injury in rats. Anesth Analg 1993;77:141-148.

24. Braughler JM, Hall ED. Acute enhancement of spinal cord synaptosomal $\left(\mathrm{Na}^{+}, \mathrm{K}^{+}\right)$-ATPase activity in cats following intravenous methylprednisolone. Brain Res 1981;219:464-469.

25. Matteucci E, Cocci F, Pellegrini L, Gregori G, Giampietro O. Measurement of ATPase in red cells: setting up and validation of a highly reproducible method. Enzyme Protein 1994-95;48:105119.

26. Ohkawa H, Ohishi N, Yagi K. Assay for lipid peroxides in animal tissues by thiobarbituric acid reaction. Anal Biochem 1979;95:351-358.

27. Lowry $\mathrm{OH}$, Rosebrough $\mathrm{NJ}$, Farr AL, Randall R. Protein measurement with the folin phenol reagent. J Biol Chem 1951;193:265-275.

28. Motulsky HJ. GraphPad. San Diego: GraphPad Software Inc 19941995.

29. Adelson PD, Whalen MJ, Kochanek PM, Robichaud P, Carlos TM. Blood brain barrier permeability and acute inflammation in two models of traumatic brain injury in the immature rat: a 
preliminary report. Acta Neurochir Suppl (Wien) 1998;71:104106.

30. Whalen MJ, Carlos TM, Kochanek PM, Heineman S. Blood-brain barrier permeability, neutrophil accumulation and vascular adhesion molecule expression after controlled cortical impact in rats:a preliminary study. Acta Neurochir Suppl (Wien) 1998;71:212-214.

31. Barzo P, Marmarou A, Fatouros P, Corwin F, Dunbar J. Magnetic resonance imaging-monitored acute blood-brain barrier changes in experimental traumatic brain injury. $\mathrm{J}$ Neurosurg 1996;85:1113-1121.

32. Fukuda K, Tanno H, Okimura Y, Nakamura M, Yamaura A. The blood-brain barrier disruption to circulating proteins in the early period after fluid percussion brain injury in rats. J Neurotrauma 1995; 12:315-324.

33. Barzo P, Marmarou A, Fatouros P, Hayasaki K, Corwin F. Biphasic pathophysiological response of vasogenic and cellular edema in traumatic brain swelling. Acta Neurochir Suppl (Wien) 1997;70:119-122.

34. Ildan F, Polat S, Gocer AI, et al. The effects of the pretreatment of intravenous high dose methylprednisolone on $\mathrm{Na}\left({ }^{+}\right)-\mathrm{K}\left({ }^{+}\right) / \mathrm{Mg}\left({ }^{+2}\right)-$ ATPase and lipid peroxidation and early ultrastructural findings following middle cerebral artery occlusion in the rat. Acta Neurochir (Wien) 1996;138:338-345.

35. Jamme I, Petit E, Gerbi A, et al. Changes in ouabain affinity of $\mathrm{Na}^{+}$, $\mathrm{K}^{+}$-ATPase during focal cerebral ischaemia in the mouse. Brain Res 1997;774:123-130.

36. Parsons JT, Churn SB, DeLorenzo RJ. Ischemia-induced inhibition of calcium uptake into rat brain microsomes mediated by $\mathrm{Mg}^{2+} / \mathrm{Ca}^{2+}$ ATPase. J Neurochem 1997;68:1124-1134.

37. Boldyrev AA, Bulygina AR. $\mathrm{Na}^{+} / \mathrm{K}^{+}$-ATPase and oxidative stress. In: Beaugé LA, Gadsby DC, Garrahan PJ (Eds). $\mathrm{Na}^{+} / \mathrm{K}^{+}$-ATPase and related transport ATPase: Structure, mechanism, and regulation. Ann NY Acad Sci 1997;834:666-668.

38. Kaplan P, Matejovicova M, Mezesova V. Iron-induced inhibition of $\mathrm{Na}^{+}, \mathrm{K}^{+}$-ATPase and $\mathrm{Na}^{+} / \mathrm{Ca}^{2+}$ exchanger in synaptosomes: protection by the pyridoindole stobadine. Neurochem Res 1997;22:1523-1529.

39. Durmaz R, Inal M, Angin M, Atasoy MA, Tel E. The effects of MK801 and $\mathrm{U}-83836 \mathrm{E}$ on post-ischemic reperfusion injury rat brain. Acta Neurobiol Exp (Warsz) 1999;59:99-104.

40. Schneider GH, Unterberg A, Lanksch WR. 21-Aminosteroid U$74389 \mathrm{~F}$ reduces vasogenic brain edema. Acta Neurochir (Wien) Suppl 1994;60:516-518.

41. Audus KL, Guillot FL, Braughler JM. Evidence for 21-aminosteroid association with the hydrophobic domains of brain microvessel endothelial cells. Free Radic Biol Med 1991;11:361-371.

42. Schoettle RJ, Kochanek PM, Magargee MJ, Uhl MW, Nemoto EM. Early polymorphonuclear leukocyte accumulation correlates with the development of post-traumatic cerebral edema in rats. $\mathbf{J}$ Neurotrauma 1990;7:207-217.

43. Kimelberg HK. Brain edema In: Kettenmannh H, Ranson BR (Eds). Neuroglia, New York,Oxford University Press, 1995: 919-935.

44. Cortez SC, McIntosh TK, Noble LJ. Experimental fluid percussion brain injury: vascular disruption and neuronal and glial alterations. Brain Res 1989;482:271-282. 